\title{
ЕФЕКТИВНІСТЬ ЗАСТОСУВАННЯ Ц-ГЛУТАМННОВОЇ КИСЛОТИ У КЛІНІЧНО ЗДОРОВИХ КОТІВ ГЕРІАТРИЧНОГО ВІКУ
}

\author{
Л. Франчук-Крива, М. Кривий, К. Гребенюкова \\ Одеський державний аграрний університет
}

Встановлено, щуо пероральне введення L-глютамінової кислоти призводило до підвищення вмісту глобулінів $i$ загального білку на 15,1 i 7,1\%, а також зростання концентрації сечовини $i$ триглічеридів на 12,4 і 40,6 \% у межах фізіологічної норми. Отримані дані опосередковано вказують на нормалізацію білкового і ліпідного обміну та активізацію гуморального імунітету в організмі геріатричних тварин.

Ключові слова: коти, геріатричний вік, старіння, L-глутамінова кислота

Постановка проблеми. Коти (Felis catus) є найпопулярнішими тваринами-компаньйонами. В світі понад 600 мільйонів котів живуть поряд з людьми [8]. За окремими даними, Україна входить в десятку країн світу з найбільшою популяцією домашніх котів, яка становить понад 7,5 млн [6]. Однією 3 провідних причин розширення популяції є подовження тривалості життя домашніх котів завдяки покращенню харчування i ветеринарного супроводу. Паралельно збільшилась і кількість літніх котів, що оглядаються ветеринарами [15, с. 85]. На даний час вважається, що 30-50 \% домашніх котів мають вік від семи років і старше; $13 \%$ - від 12 років і старше [14, с. 687]. Старіння, як фізіологічний процес, не є хворобою, але включає поступову незворотну втрату регенераторних і резервних можливостей органів та систем організму, що, в цілому, сприяє розвитку захворювання $[7,12]$. Тому спільним між хворобою і старінням $\epsilon$ те, що обидва процеси ведуть до зниження життєздатності організму. Механізми старіння досі вважаються до кінця не вивченими. Відомо, що при старінні знижуються адаптаційні можливості організму, а екзогенні і ендогенні подразники викликають на цьому тлі стрес-синдром, який надає неоднозначний вплив на темп вікових змін та тривалість життя тварини [2, с. 9]. Водночас, для багатьох людей смерть тварини-компаньйона - означає непоправну втрату улюбленого члена сім’i.

Враховуючи наведене, пошук засобів для підвищення адаптаційних i репаративних можливостей організму геріатричних тварин мають безумовну науково-практичну цінність.

Аналіз актуальних досліджень. Амінокислоти та їх похідні давно та ефективно застосовуються в терапевтичній практиці у вигляді самостійних лікарських засобів - цистеїн, лізин, гліцин, аргінін, глутамін або в складі комплексних лікарських препаратів (амінол, аміновітол, гепаксин, глутаргін тощо). Також амінокислоти відносять до компонентів фармакологічного харчування (нутрицевтикам), які дозволяють коригувати функціональні розлади органів і організму в цілому [3, с. $14 ; 5$, с. 2].

Аналізуючи наукові роботи бази даних NCBI Pubmed за період з 1996 по 2020 рр. помітно значний інтерес науковців до глутамінової кислоти (глутамін, Gln, L-глутамінова кислота).

Глутамін вважається умовно замінною амінокислотою. Однак доведено, що клітини, які мають швидкий поділ, в тому числі слизової оболонки кишечнику, підшлункової залози, альвеол і імунної системи використовують глутамін для енергетичних і пластичних потреб [10, 11].

3 функціональних позицій, глутамін $є$ донатором азоту для синтезу аміноцукрів, пуринів $\mathrm{i}$ піримідинів, з яких, в подальшому, утворюються азотисті сполуки, необхідні для проліферації і синтезу білків $[4$, с. $15 ; 10,17]$.

Інтрацелюлярні і позаклітинні концентрації глютаміну значно знижуються у відповідь на інфекцію, запалення, сепсис, тяжкі опіки, неоплазії, стрес та інші патологічні стани. За цих умов потреба в глутаміні підвищується i, досі замінна амінокислота, переходить в розряд есенціальних $[16$, c. $18 ; 17]$.

Водночас, глутамінова кислота відноситься до нейромедіаторних речовин, які стимулюють передачу збудження в синапсах ЦНС. Глутамін сприяє синтезу ацетилхоліну, АТФ та перенесенню іонів калію [1]. 
Експериментальними і клінічними дослідженнями доведено, що введення глютаміну до або після хірургічного втручання, опіків знижує інтенсивність кишкової проникності, тим самим зменшуючи транслокацію бактерій і токсинів [4, 12].

За окремими дослідженнями (Baylos M. et al., 2008) визначено, що додавання 1 \% Lглутамінової кислоти до раціону кролів зменшувало кількість умовно-патогенної мікрофлори в кишечнику i, особливо - Clostridium perfringens [9, с. 529].

Ряд авторів (Gaukav K. et al., 2012) довели, що введення глутаміну до протимікробної терапії зменшує імуносупресивну дію хіміопрепаратів і знижує їх нейротоксичність $[10,16]$.

Таким чином, фармаконутриєнтними ефектами глутамінової кислоти $є$ підтримання нормального функціонування імунної системи, клітинних метаболічних процесів та здатність протидіяти інфекційним ускладненням.

Перелічені ефекти глютамінової кислоти $є$ вагомою передумовою для ії подальшого дослідження і застосування з метою підтримання адаптаційно-компенсаторних реакцій організму тварин геріатричного віку.

Метою роботи було дослідити вплив L-глутамінової кислоти на клініко-фізіологічний i біохімічний статус клінічно здорових котів геріатричного віку.

Для досягнення поставленої мети були виконані наступні завдання:

-дослідити клінічний статус котів геріатричного віку;

-визначити вплив L-глютамінової кислоти на окремі показники обміну речовин у котів геріатричного віку.

Дослідження проводились на базі амбулаторії ветеринарної медицини “Animals” (м. Одеса) впродовж 2020 року. Для визначення терапевтичного ефекту L-глутамінової кислоти було сформовано дві групи - одна дослідна з котів віком 9-14 років і одна контрольна групи (n=17). Середній вік котів дослідної групи становив 11,2 $\pm 0,6$ років. Кров для біохімічного дослідження у дослідних котів відбирали двічі - на початку дослідження (до застосування препарату) і через 10 діб. За контрольні показники були прийняті результати біохімічного дослідження крові від

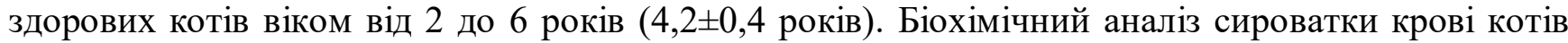
було проведено на біохімічному напівавтоматичному аналізаторі BTS-350 BioSystems (Iспанія). Формування дослідних груп проходило без урахуванням статі, маси і породи котів. Інфекційні і паразитарні захворювання у дослідних і контрольних тварин були заздалегідь виключені.

Статистична обробка даних включала розрахунок середніх величин варіаційного ряду (М) та стандартного відхилення (m). Оцінювання достовірності отриманих числових значень проводили за t-критерієм Стьюдента (Р). Відмінності між отриманими числовими показниками вважали достовірними при $\mathrm{P}<0,05$. Числові розрахунки проводили 3 використанням програми Excel.

Виклад основного матеріалу. За дослідний період (2020-2021 рр.) було зареєстровано 135 звернень власників тварин з літніми котами в віковому діапазоні від 7 до 16 років. Встановлено, що найбільший відсоток котів літнього віку становили помісні породи котів (метиси) - 70,3 \% (83 тварини). Серед порід котів, які досягли літнього віку переважну більшість становили персидська, сіамська, російська блакитна, сноу-шу і бурманська породи $-29,7 \%$.

Виявлено, що 87,4 \% котів геріатричного віку мали одну або кілька соматичних патологій. Частою причиною звернень власників котів літнього віку були пригнічення $(99,2 \%)$, анорексія (98,3 \%), поведінкові зміни (61,9 \%), періурія (52,5\%), дизурія (43,2 \%), закреп (42,3 \%), діарея $(35,6 \%)$, гематурія $(32,2 \%)$, диспное $(31,4 \%)$, схуднення $(30,0 \%)$, ожиріння $(21,2 \%)$, кульгавість $(19,4 \%)$, рани (12,7\%), алопеції (7,6 \%), новоутворення $(2,5 \%)$.

В меншій мірі у літніх котів виявляли новоутворення - 3 випадки. В більшості випадків, неоплазії локалізувались у ротовій порожнині (фіброматозний епуліс) і молочній залозі. Також було зареєстровано один випадок поліпів у сечовому міхурі кота, віком 14 років (рис. 1).

За результатами клінічного дослідження, найбільш поширеними захворюваннями котів літнього віку виявились хронічна ниркова недостатність, уроцистит і гепатодистрофія, на сумарну частку яких припадало 77,1 \% тварин. Необхідно відмітити, що у 74,6 \% геріатричних котів діагностовано сумісний перебіг одночасно 2-х і більше соматичних захворювань. У 54,2 \% випадків множинна патологія у літніх котів була викликана гепато-ренальним синдромом. Таким 
чином, центральні органи метаболізму і екскреції - печінка і нирки з віком зазнають патологічних змін найбільше.

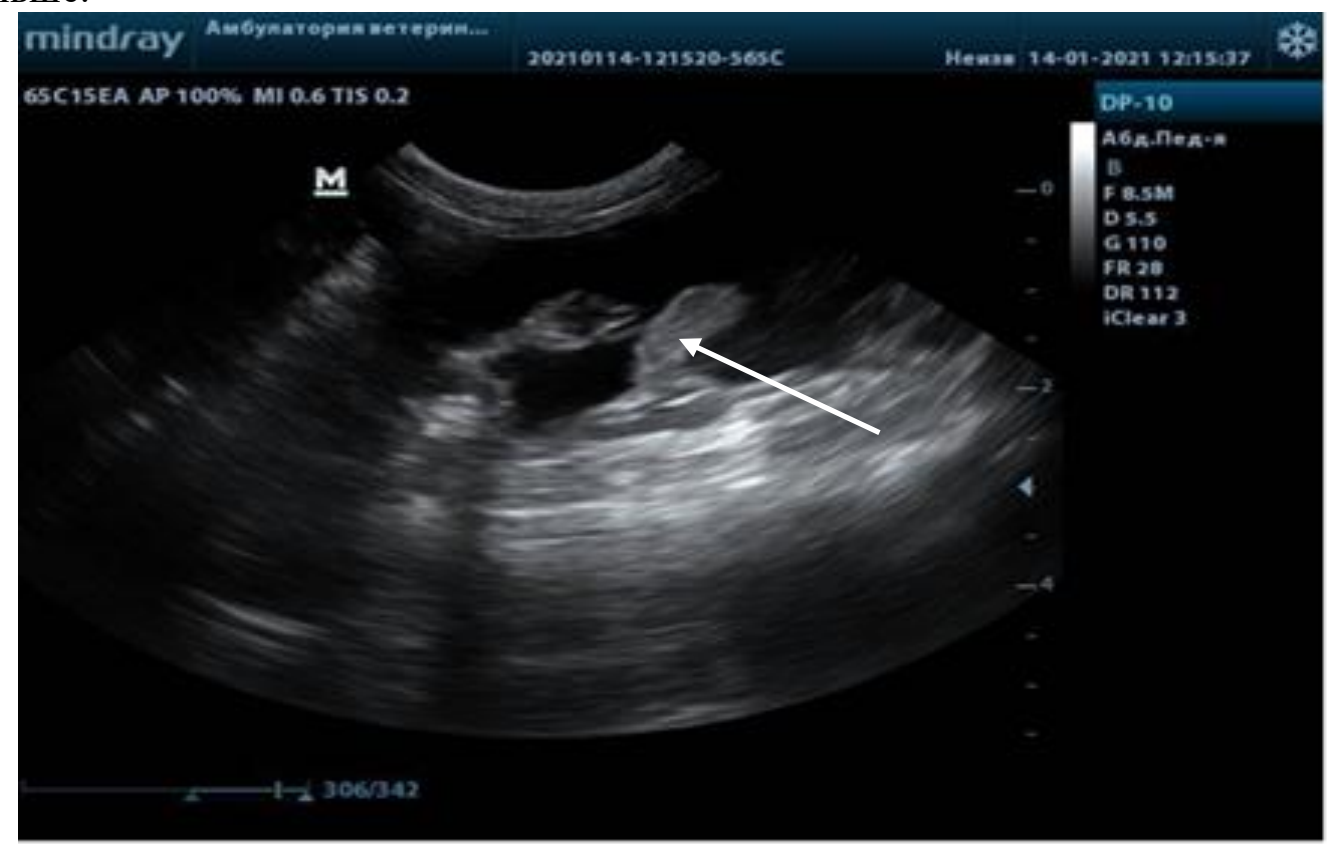

Рис. 1. Поліпи в сечовому міхурі у кота (самець, метис, 14 років)

Виявлено, що пероральне введення L-глютамінової кислоти котам геріатричного віку мало позитивний вплив на динаміку біохімічних показників крові, які характеризують білковий обмін (табл. 1).

Таблиця 1.Вплив L-глютамінової кислоти на біохімічні показники крові клінічно здорових котів геріатричного віку $(\mathrm{n}=17, \mathrm{M} \pm \mathrm{m})$

\begin{tabular}{|c|c|c|c|}
\hline \multirow{2}{*}{ Показники } & \multicolumn{2}{|c|}{ Групи } & \multirow{2}{*}{$\begin{array}{c}\text { Контрольна } \\
\text { група }\end{array}$} \\
\hline & До застосування & Через 10 діб & \\
\hline Загальний білок, г/л & $61,7 \pm 2,0$ & $66,4 \pm 1,2 *$ & $68,9 \pm 1,8$ \\
\hline Альбумін, г/л & $29,1 \pm 1,0$ & $28,8 \pm 0,9$ & $34,3 \pm 1,5$ \\
\hline Глобуліни, г/л & $32,5 \pm 2,4$ & $38,3 \pm 1,2 *$ & $34,6 \pm 2,1$ \\
\hline $\mathrm{A} / \Gamma$ & $1,0 \pm 0,1$ & $1,0 \pm 0,1$ & $1,0 \pm 0,1$ \\
\hline Сечовина, ммоль/л & $7,8 \pm 0,3$ & $8,9 \pm 0,3 *$ & $4,5 \pm 0,3$ \\
\hline Креатинін, мкмоль/л & $178,3 \pm 12,2$ & $179,4 \pm 9,5$ & $97,8 \pm 7,0$ \\
\hline Глюкоза, ммоль/л & $6,3 \pm 0,6$ & $5,9 \pm 0,5$ & $5,4 \pm 0,1$ \\
\hline Білірубін заг., мкмоль/л & $3,6 \pm 0,5$ & $3,9 \pm 0,4$ & $4,0 \pm 0,3$ \\
\hline $\mathrm{AcAт,Од/л}$ & $40,0 \pm 4,3$ & $33,0 \pm 2,6$ & $26,1 \pm 1,4$ \\
\hline АлАт,Од/л & $72,3 \pm 5,6$ & $68,1 \pm 4,8$ & $47,3 \pm 3,4$ \\
\hline Тригліцериди, ммоль/л & $0,76 \pm 0,16$ & $1,28 \pm 0,2 *$ & $0,78 \pm 0,1$ \\
\hline Лужна фосфатаза, Од/л & $70,8 \pm 9,8$ & $62,1 \pm 6,7$ & $52,1 \pm 5,6$ \\
\hline ГГТП, Од/л & $9,4 \pm 0,3$ & $7,8 \pm 0,9$ & $7,6 \pm 0,5$ \\
\hline а-амілаза, Од/л & $1030,7 \pm 102,7$ & $874,1 \pm 79,9$ & $963,0 \pm 111,0$ \\
\hline
\end{tabular}

Примітка: *P<0,05 - вірогідність даних, порівняно до показників контрольної групи

Вміст загального білку в крові дослідних тварин до початку дослідження наближався до нижньої межі норми і становив $61,7 \pm 2,0$ г/л. Після застосування L-глютамінової кислоти виявлено статистично вірогідне підвищення вмісту загального білку на $7,1 \%(\mathrm{P}<0,05)$ за рахунок зростання рівня глобулінів.

Вміст глобулінів в сироватці крові дослідних котів статистично достовірно підвищився на $15,1 \%(\mathrm{P}<0,05)$. Отримані результати, ймовірно, пов'язані із активізацією гуморальної ланки імунної системи у тварин під впливом L-глутамінової кислоти.

Порівняно з глобулінами, вміст альбумінів у сироватці крові котів літнього віку після

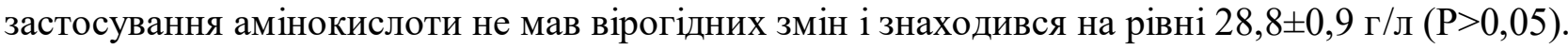


На 10 добу введення L-глютамінової кислоти в сироватці крові котів реєстрували підвищення концентрації сечовини в референтних межах на $12,4 \%(\mathrm{P}<0,05)$. Так як, сечовина $\epsilon$ кінцевим продуктом обміну білків, який продукується в печінці, іiі підвищення, ймовірно, пов'язано із зростанням рівня загального білку і покращенням метаболізму в гепатоцитах.

Відмічено статистично вірогідне підвищення вмісту тригліцеридів в сироватці крові дослідних тварин на 40,6 \% (P<0,05) через 10 діб введення препарату. Дана тенденція, ймовірно, пояснюється активізацією метаболічних процесів у клітинах основних органів синтезу ендогенних тригліцеридів - тонкому кишечнику і печінці.

Натомість, вміст креатиніну до і після застосування препарату варіював в межах $178,3 \pm 12,2-$ $179,4 \pm 9,5$ мкмоль/л та не мав статистично вірогідних змін ( $\mathrm{P}>0,05)$.

Подібна тенденція спостерігалась і відносно таких показників як глюкоза, білірубін і ферменти крові (АсАт, АлАт, ГГТП, лужна фосфатаза) - до і після введення L-глютамінової кислоти зміни їх рівня у сироватці крові не досягали статистичної достовірності $(\mathrm{P}>0,05)$.

Таким чином, пероральне введення L-глютамінової кислоти у дозі 0,5 г на кг м.т. тварини 2 рази на добу впродовж 10 діб призводило до підвищення вмісту глобулінів і загального білку на 15,1 і 7,1 \% відповідно, а також зростання концентрації сечовини і тригліцеридів на 12,4 і 40,6 \% у межах норми. Отримані дані опосередковано вказують на нормалізацію білкового і ліпідного обміну та активізацію гуморального імунітету в організмі геріатричних тварин.

\section{Висновки і перспективи подальших досліджень.}

1. Встановлено, що найбільший відсоток котів літнього віку становлять помісні породи котів $-70,3 \%$.

2. Поширеними захворюваннями котів літнього віку виявились хронічна ниркова недостатність, уроцистит і гепатодистрофія, на сумарну частку яких припадало 77,1% тварин.

3. Пероральне введення L-глютамінової кислоти у дозі 0,5 г на кг маси тіла тварини 2 рази на добу впродовж 10 діб призводило до підвищення вмісту загального білку і глобулінів на 7,1 i $15,1 \%$, а також зростання концентрації сечовини і тригліцеридів на 12,4 і 40,6 \% відповідно, у межах фізіологічної норми.

Перспективою подальших досліджень $є$ визначення ефективності L-глютамінової кислоти за синдрому когнітивних дисфункцій у собак і котів геріатричного віку.

\section{Список використаних джерел:}

1. Глутаминовая кислота (Acidum glutaminicum) / Компендиум: лекарственные препараты. Справочник ЛС № 1 в Украине. URL: https://compendium.com.ua/info/61080/glutaminovaja-kislota/ (дата обращения: 20 декабря 2020 г.).

2. Ишонина О.Г. Старение организма - универсальная болезнь или неизбежно возникающий процесс? Медицинский вестник. Обзоры. 2011. С. 9-11.

3. Климович И.И., Дорошенко Е.М., Страпко В.П., Смирнов В.Ю. Аминокислоты в лечении биллиарной патологии (обзор литературы). Журнал ГрГМУ. 2008. № 1. С. 14.

4. Луфт В.М., Дмитриев А.В., Сизова Н.В. Глутамин и его производные в коррекции метаболических нарушений у ВИЧ-инфицированных пациентов. Медицинский академический журнал. 2015. Т. 15, № 2. С. 15-16.

5. Салтанов А.И. Снеговой А.В. Применение фармаконутриентов в онкологической практике. Вестник Московского онкологического общества. 2009. № 5. С. 2-3.

6. Украина для котов. Рейтинг стран-рекордсменов по количеству домашних животных. Инфографика. TCH. URL: https://tsn.ua/ru/tsikavinki/ukraina-dlya-kotov-reyting-stran-rekordsmenovpo-kolichestvu-domashnih-zhivotnyh-604202.html (дата обращения: 2 января 2021 г.).

7. Клаучек С.В., Лифанова Е.Ф. Физиология стареющего организма: Уч.пособие. ВолгГМУ : Волгоград, 2007. 42 с.

8. Atsuko Saito, Kazutaka Shinozuka, Yuki Ito, Toshikazu Hasegawa. Domestic cats (Felis catus) discriminate their names from other words. Sci Rep. 2019. Vol. 9. doi: 10.1038/s41598-01940616-4. 
9. Effect of dietary level and source of glutamine on intestinal health in the postweaning period Baylos M et al. Nutrition and Digestive Physiology: 9th World Rabbit Congress (June 10-13, 2008, Verona, Italy). 2008. P. 529-532.

10. Glutamine depletion induces murine neonatal melena with increased apoptosis of the intestinal epithelium Motoki T. et al. World J. Gastroenterol. 2011. Vol. 17(6). P. 717-726. doi: 10.3748/wjg.v17.i6.717.

11. Gaurav Kumar, Goel R K, Shukla Mridula, Pandey Manoj Glutamine: A novel approach to chemotherapy-induced toxicity. Indian J Med Paediatr Oncol. 2012. Vol. 33 (1). P. 13-20. doi: 10.4103/0971-5851.96962.

12. Gunn-Moore A. Danielle. Cognitive dysfunction in cats: clinical assessment and management. Top Companion Anim Med. 2011. Vol. 26 (1). P. 17-24. doi: 10.1053/j.tcam.2011.01.005.

13. Gunn-Moore D., Moffat K., Christie L-A, Head E. Cognitive dysfunction and the neurobiology of ageing in cats J Small Anim Pract. 2007. Vol. 48 (10). P. 546-53. doi: 10.1111/j.17485827.2007.00386.x.

14. Pet feeding practices of dog and cat owners in the United States and Australia. Laflamme D.P. et al. J. Am. Vet. Med Assoc. 2008. Vol. 232. P. 687.

15. Prevalence of disease and age-related behavioural changes in cats: past and present. Sordo L.et al. Vet. Sci. 2020. Vol. 7. P. 85; doi:10.3390/vetsci7030085.

16. Protective effects of L-glutamine on the bladder wall of rats submitted to pelvic radiation. Leilane M Barcellos et al. Micron. 2013. Vol. 47. P. 18-23. doi: 10.1016/j.micron.2013.01.001.

17. Regulation of protein metabolism by glutamine: implications for nutrition and health Xi Pengbin et al. Front Biosci. 2011. Vol. 16. P. 578-597. doi: 10.2741/3707.

\section{ЭФФЕКТИВНОСТЬ ПРИМЕНЕНИЯ L-ГЛУТАМИНОВОЙ КИСЛОТЫ У КЛИНИЧЕСКИ ЗДОРОВЫХ КОШЕК ГЕРИАТРИЧЕСКОГО ВОЗРАСТА}

Франчук-Кривая Л., Кривой Н., Гребенюкова Е.

Выявлено, что пероральное введение L-глутаминовой кислоты приводит к повышению содержания глобулинов и общего белка на 15,1 и 7,1\%, а также повышению концентрации мочевины и тригличеридов на 12,4 и 40,6 \% в пределах физиологической нормы. Полученные данные косвенно указывают на нормализацию белкового и липидного обмена и активизацию гуморального иммунитета в организме животных гериатрического возраста.

Ключевые слова: коты, гериатрический возраст, старение, L-глутаминовая кислота.

\section{THE EFFICACY OF L-GLUTAMIC ACID IN CLINICALLY HEALTHY GERIATRIC CATS}

Franchuk-Kryva L., Kryvyi M., Hrebeniukova K.

It was found that oral administration of L-glutamic acid led to an increase in the content of globulins and total protein by 15.1 and $7.1 \%$, as well as an increase in the concentration of urea and triglycerides by 12.4 and $40.6 \%$ within the physiological norm. The data obtained indirectly indicate the normalization of protein and lipid metabolism and activation of humoral immunity in geriatric pets.

Key words: cats, geriatric age, aging, L-glutamic acid. 